\title{
Circum-Pacific Faulting in the Philippines-Taiwan Region ${ }^{1}$
}

\author{
Clarence R. Allen \\ Division of Geological Sciences \\ California Institute of Technology, Pasadena
}

\begin{abstract}
Conflicting views of circum-Pacific tectonics have focused on the PhilippinesTaiwan region, where there has been neither convincing documentation nor general agreement on the importance of transcurrent (strike-slip) faulting or the possible sense of regional horizontal displacement. Structural and physiographic features of the $1200-\mathrm{km}$-long Philippine fault zone are fully as spectacular as those of the better-known San Andreas and Alpine faults, and current activity is indicated by many localities in which scarps cut Recent gravels. Predominance of horizontal over vertical displacements is indicated by linearity of the fault trace, failure of one side to be consistently higher than the other, disregard for gross physiography, and scissoring of individual scarps within the zone. Consistent stream offsets on Luzon, Masbate, and Leyte demonstrate unequivocally that the sense of Recent displacement has been uniformly sinistral (left-handed). The Philippine fault has no obvious geologic relationship to active volcanoes, but the parallelism and proximity of the fault to the Mindanao trench suggest a close causal relationship. The remarkable Longitudinal Valley of eastern Taiwan represents another great transcurrent fault parallel to the western Pacific rim, and ground displacements during historic earthquakes indicate a sinistral sense of displacement here as well as in the adjacent Philippines. This study does not support the hypothesis of counterclockwise rotation of the Pacific basin, but more important is the further documentation of the predominance of transcurrent faulting in active circum-Pacific orogenic areas. These results reinforce earlier field studies in Alaska, California, Chile, and New Zealand, as well as emphasizing the geological reasonability of the results of seismic fault-plane solutions indicating the world-wide predominance of transcurrent movements.
\end{abstract}

\section{The Problem}

The purpose of this study was to investigate some of the major faults of the PhilippinesTaiwan region with the hope of unequivocally demonstrating their extent, their degree of current activity, and-particularly-their sense of displacement. Unusual geophysical significance is attached to this region because widely divergent views of circum-Pacific orogeny focus here, especially concerning the question of the relative importance of horizontal fault displacements. Even granting the importance of horizontal movements, major disagreement has existed concerning the sense of possible displacement: theories of Benioff [1959] and St. Amand [1959] implied the probable existence of dextral or right-handed faults paralleling the western Pacific margin in this region, whereas theories of Vening Meinesz [1954] and $B i q$ [1960] supposed sinistral or left-handed dis-

1 Contribution 1099, Division of Geological Sciences, California Institute of Technology. placements in this same region. In both hypotheses, the assumed sense of displacement played a part in the interpretation of the general mechanism of circum-Pacific orogeny. Van Bemmelen [1949] and others have tended to discount the importance of horizontal fault displacements in this region altogether.

Willis [1937] was apparently the first investigator to recognize the existence of a throughgoing fault zone in the Philippines comparable to the San Andreas fault in California, although numerous workers dating back to von Drasche [1878] had pointed out the existence of various tectonic lineaments in the archipelago, mainly on the basis of the alleged alignment of islands, volcanoes, and earthquake epicenters. Repetti [1935], in particular, had proposed the 'Master fault' along the general trend of the Philippine fault zone, but his evidence other than that from northern Luzon was based almost wholly on inconclusive seismic data. The term 'Philippine fault zone' used by Willis [1937] seems to have become well established in the literature, notwithstanding the later use by 
Willis [1944] of 'Visayan rift' for the same feature.

Von Drasche $[1878$, p. 3$]$ and others had particularly pointed out the bifurcation or virgation of tectonic trends in the southern Philippines, the southwesterly trend of the islands in the southwestern Philippines contrasting sharply with the southeasterly trend of the islands and mountain chains along the southeastern rim of the archipelago. The island of Masbate, ${ }^{1}$ with its two diverging 'arms,' has often been cited as an example of the acute junction of the two opposing trends. Willis was so impressed by the linearity of the southeasterly trending features between Ragay Gulf and northern Mindanao that he proposed the existence of the Philippine fault zone along this line; his evidence was admittedly based almost wholly on gross physiographic forms. Other investigators who followed Willis have generally agreed upon the presence of a fault zone, although there have been disagreements concerning its possible extension into northern Luzon and its exact location in the central part of the islands. Evidence for its existence has continued to be based mainly on gross physiography, inasmuch as there is no clear documentation of displacements along its trace during historic earthquakes. Only on the island of Mindanao do published geologic maps clearly demonstrate and delineate the various breaks that make up the Philippine fault zone [Ranneft et al., 1960]. Probably the most accurate maps of the fault's location north of Mindanao, and the most cogent arguments for its existence, are those by Irving [1951, 1953], based in part on an analysis of the submarine morphology of the region.

Willis apparently considered the Philippine fault to be dominantly transcurrent (i.e., 'strikeslip,' 'lateral,' or 'wrench') because of its similarity to the San Andreas fault, particularly in its length, linearity, and general physiographic expression. But the sense of horizontal displacement has been the subject of more nebulous argument. Willis argued that the fault was sinistral, and the most often-quoted evidence is based on a single set of horizontal asymmetric slickensides that were observed by Willis [1937, p. 39] in the Aroroy mining district on Masbate, although this particular fault is subsidiary to

${ }^{1}$ All Philippine place names used in the text are indicated on Figures 1 and 2. the main zone and is apparently at an angle of at least $30^{\circ}$ to it. Willis further argued that the regional plan of the islands suggested a sinistral sense of displacement. Other authors have agreed [Alvir, 1941; King and McKee, 1949]. But opinion has not been unanimous; Irving [1951, p. 70] thought that many of the offsets implied by such arguments were 'excessive,' and Alvir [1926, p. 453] had used the same kind of argument (based on gross physiographic features) to indicate dextral displacement along the fault in northern Luzon that is herein considered to be an integral part of the Philippine fault zone.

Another line of evidence bearing on the sense of fault displacement is that given by fracture patterns in Philippine mining areas, although none of the areas described in detail has been within the fault zone proper. Leith [1938], Livingston [1939], and Wisser [1939] pointed out that the pervasive shear and tension joints of the Baguio mining district demand east-west compression, at least in Miocene time, as does the general trend of the folded mountain ranges north of Manila. Wisser [1952] cited supporting evidence from local fracture patterns in southeastern Luzon and northeastern Mindanao. Such east-west compression is, of course, compatible with sinistral transcurrent displacement on the Philippine fault zone but by no means proves it. Nor has there been complete agreement on the regional stress pattern; the numerous northsouth lineaments of the central Philippines were visualized by Alcaraz [1947] as tensional in origin, which implies a regional stress system that would lead to dextral displacement along the Philippine fault zone. Ranneft et al. [1960] indicated sinistral displacements on individual breaks of the zone in northeastern Mindanao but did not state why.

It might be hoped that results of seismic faultplane solutions on the numerous earthquakes of the Philippines region would clear up the ambiguity resulting from the limited geologic studies. In a summary of 35 fault-plane solutions from this region, Ritsema and Veldkamp [1960] state that the predominant displacements have indeed been transcurrent and sinistral, and the implied direction of horizontal compression is about $\mathrm{N} 60^{\circ} \mathrm{E}$. None of the larger earthquakes of this group, however, occurred within the Philippine fault zone, and the largest shock $(M=8.2$, Jan. 24,1948$)$ was clearly dextral. 
The epicenter of this great earthquake was near the west coast of Panay, where there is good evidence of a major northeast-trending fault that might reasonably be considered conjugate to the Philippine fault and thus dextral. The fault-plane solution, however, which is supported by the trend of the isoseismals [Irving and Teves, 1948], indicated failure on a fault striking more nearly parallel to the Philippine fault than to the local structure. Furthermore, $A k i$ 's [1960] source-function solutions based on Rayleigh waves continue to indicate dextral displacements around the entire circum-Pacific margin. The one Philippine earthquake included in Aki's solutions indicates breaking on a fault sub-parallel to the Philippine fault in the northern Central Valley of Luzon, and it is clearly dextral.

Thus, in brief, it was not clear at the beginning of this study that the Philippine fault zone (1) indeed existed, at least as a throughgoing feature of regional tectonic importance, (2) was active, and (3) was necessarily a transcurrent and sinistral feature. Furthermore, it was hoped that if the Philippine fault zone was indeed a feature representing regional horizontal shearing, then similar features might be observed in Taiwan or other adjacent circum-Pacific areas.

\section{Philippine Fault Zone}

Location and physiographic expression. Several investigators have pointed out that the Philippine fault zone encompasses a wide region of interlacing and branching fractures, so that its exact location is hard to define. This is probably true, but certainly the evidence of relatively recent displacements is confined in many areas to a single clearly defined zone, and it is this most recent or active break that is primarily shown in Figures 1 and 2. Evidence for the fault's location is based mainly on physiographic features of Quaternary displacement that are clearly visible on aerial photographs and in the field. These features include fault and faultline scarps, fault troughs and valleys, side-hill ridges, and numerous fault sags and sag ponds. In general, detailed features of active faulting are almost as well displayed along the Philippine fault as along the San Andreas fault in California, despite the extreme differences in climate.

Probably the best-displayed segment of the Philippine fault zone is in northwestern Leyte, between the towns of Visares and Leyte. The zone here consists of a number of parallel active breaks over a width of about 500 meters, and the extreme linearity of the topography within the fault zone stands in marked contrast to the topography on both sides (Figures 3-5). Neither side is consistently higher than the other, and the central part of the zone is, in general, a structurally and topographically depressed trough that has caused the term 'rift' to be applied to this fault in analogy with the similar features and nomenclature of the San Andreas fault. Indeed, the general physiography is best described in the same words used by Noble [1954, p. 37] in portraying the San Andreas: 'It has a curiously direct course across mountains and plains, with little regard for gross physiographic features, yet it influences profoundly the local topographic and geologic features within it.'

Both north and south of the central Philippines area, the fault separates into a number of branches. The fault that enters northern Luzon at Dingalan Bay is herein considered to be the main Philippine fault on the basis of its similar strike, degree of complexity, and sense of displacement as compared with the fault farther south. The alignment is not perfect, however, and possible reasons for this slight kink in the fault trace are discussed later in the paper. Along the great southwest-facing escarpment extending northwest from Dingalan Bay, physiographic features of Recent displacement are nearly as spectacular as on Leyte, although both Willis [1937, p. 20] and van Bemmelen [1949, vol. 1A, p. 34] denied the existence of faulting along most of this line. Recent fault scarps are particularly evident along the base of the range northeast of Umingan and on the divide between Dingalan Bay and the Central Valley (Figure 6). As was pointed out by Irving [1951, p. 79], however, this fault separates into a number of branches that trend north into the Cordillera Central, so that probably no single break extends completely across Luzon into Lingayen Gulf, at least at the present time. In Mindanao, a number of southward-diverging breaks have been mapped by Ranneft et al. [1960], but the most recent and continuous appearing break is that which follows the upper Agusan River and crosses the mountains to the south coast at Mati. In most of the Agusan River Valley itself, the surficial rocks are so young that it is not surpris- 


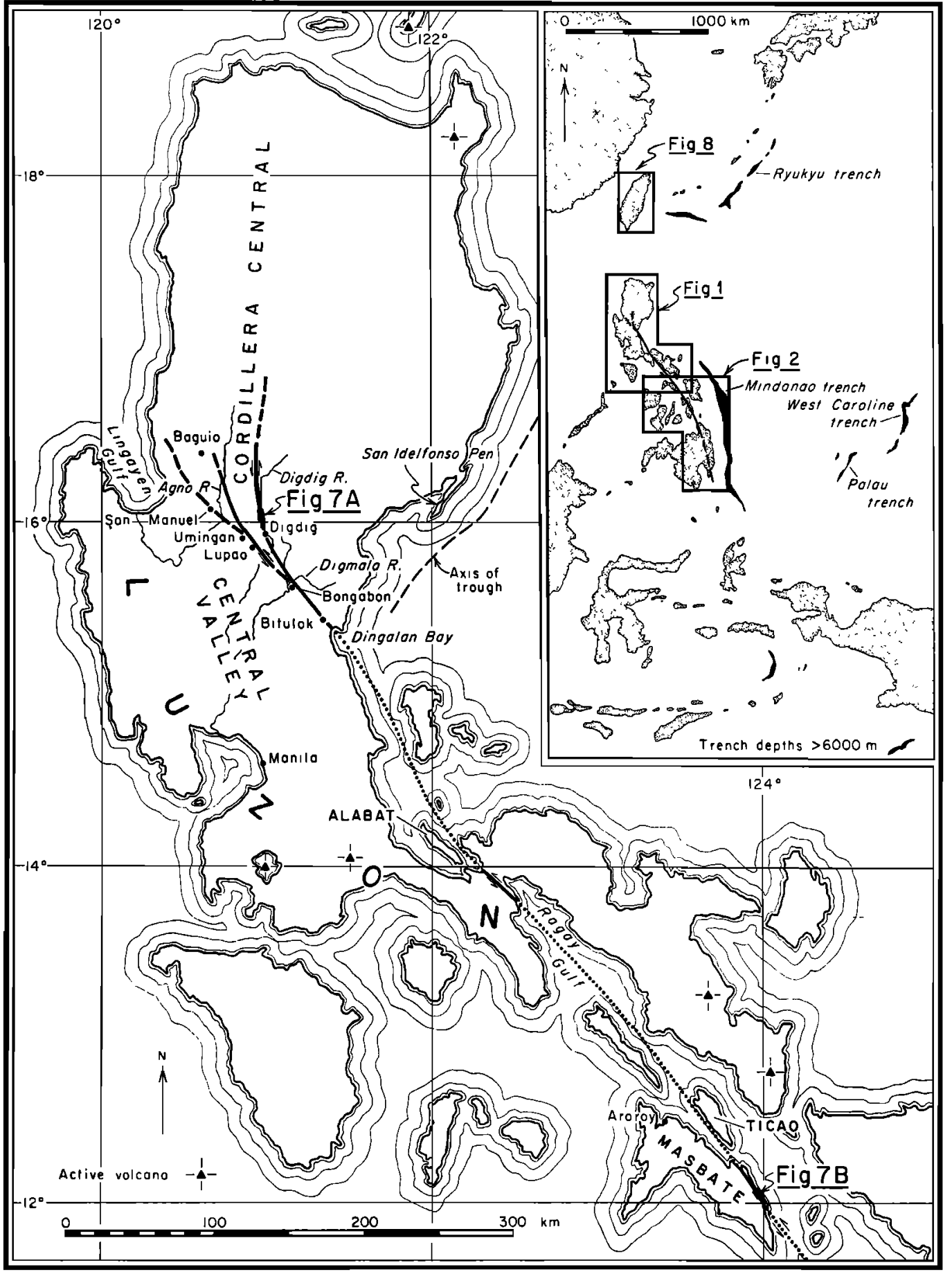

Fig. 1. Map of northern Philippines, showing place names mentioned in the text and traces of active breaks of Philippine fault zone. 


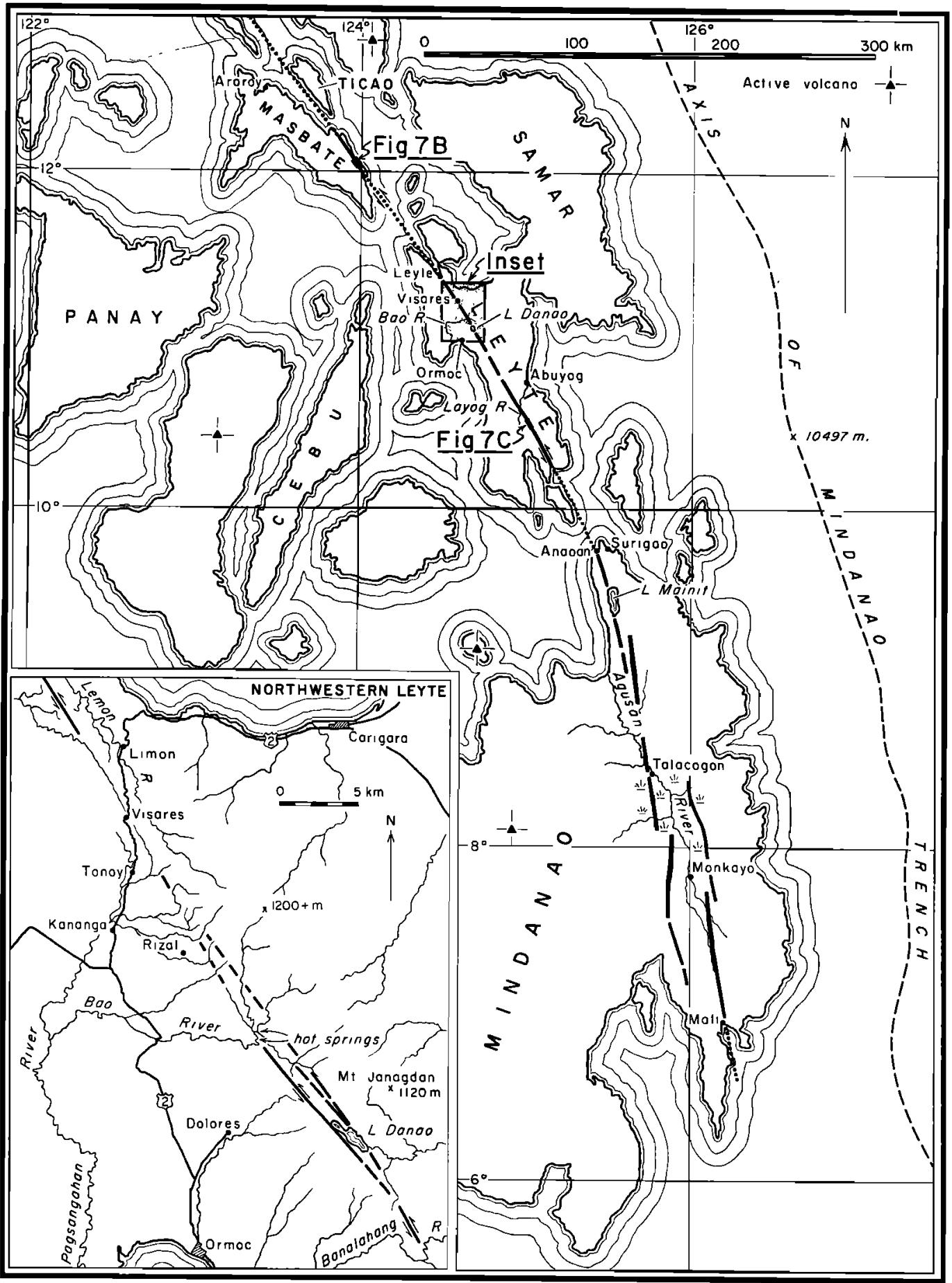

Fig. 2. Map of southern Philippines, showing place names mentioned in the text and traces of active breaks of Philippine fault zone. 

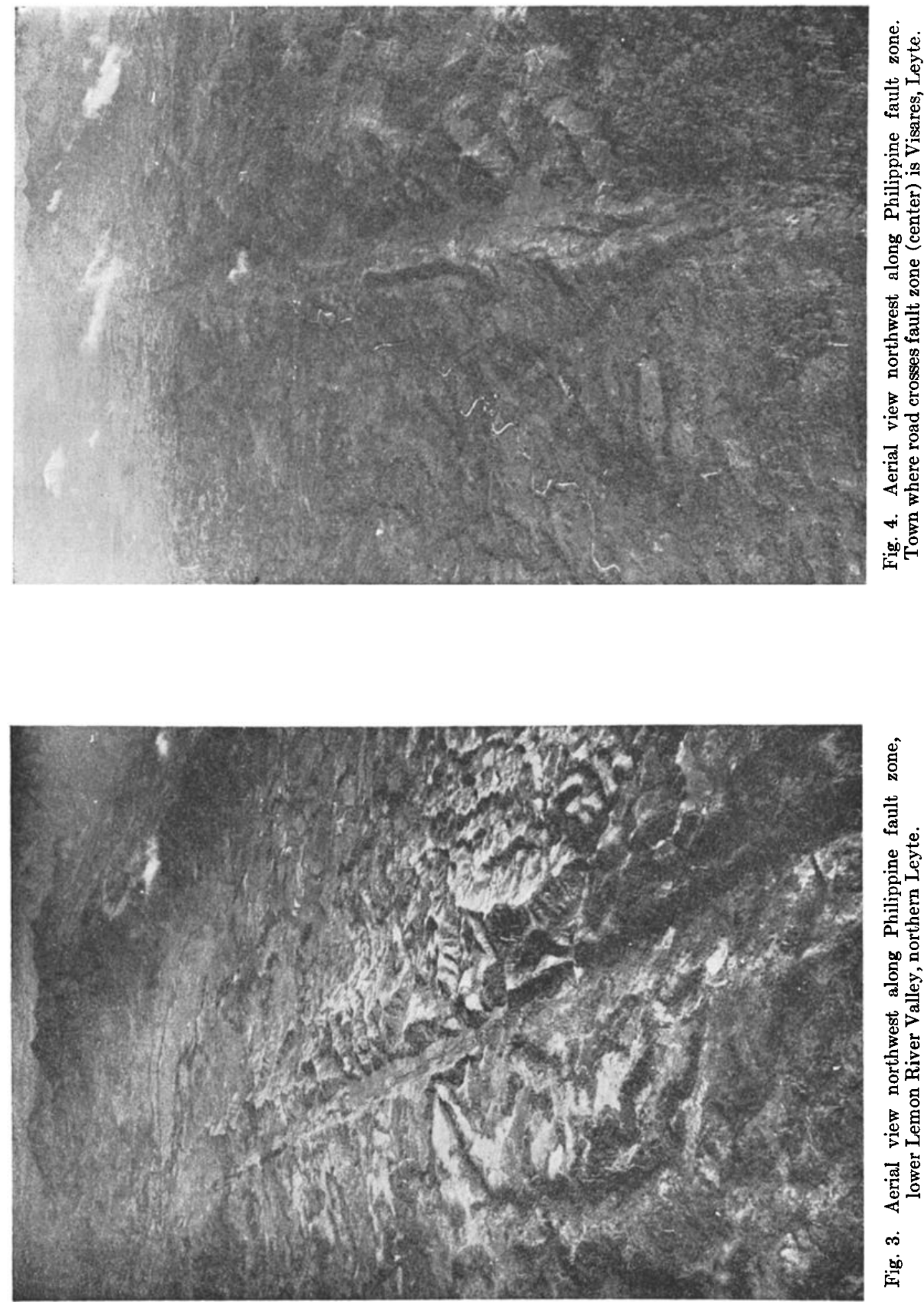


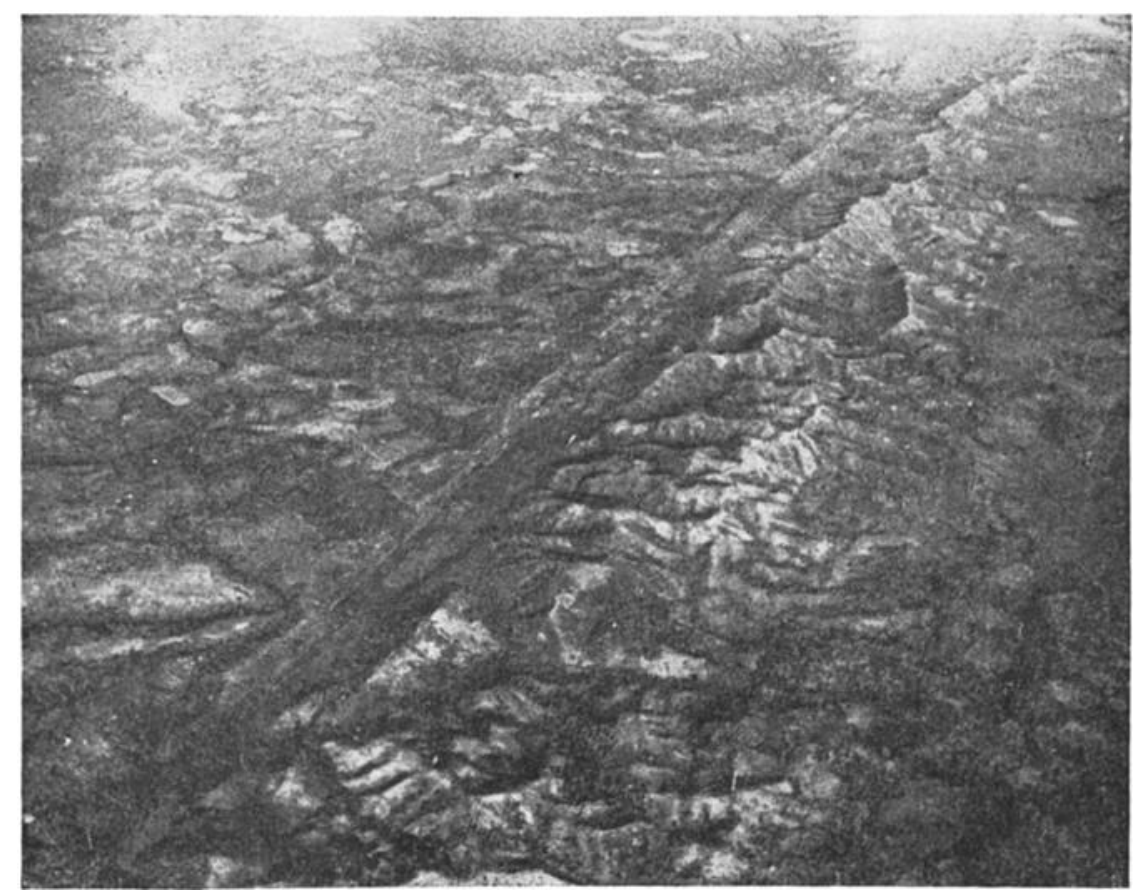

Fig. 5. Aerial view of features of Recent displacement, Philippine fault zone, northern Leyte.

ing that the fault zone there lacks obvious physiographic expression.

Current activity of the fault is demonstrated in areas in which the fault clearly breaks Recent stream gravels. Prominent examples are: (1) The fan of the Agno River in northern Luzon is cut by a distinct scarp that passes through the northern part of the town of San Manuel and decreases in height as it approaches the present course of the river. (2) The fan of the Digmala River is clearly broken for at least 5 $\mathrm{km}$ along the fault that passes $2 \mathrm{~km}$ northeast of Bongabon, Luzon. The southwest side of this fault is raised about 1 meter. Along this same branch of the fault, $40 \mathrm{~km}$ farther northwest, Recent gravels of the Digdig River are broken $0.3 \mathrm{~km}$ east of Digdig. (3) On the island of Mindanao, Recent flood-plain deposits of the Agusan River are broken for many kilometers along the fault that passes $0.5 \mathrm{~km}$ west of Talacogon, as was pointed out to the author by F. C. Gervasio. Ranneft et al. [1960] show many branches of the fault in eastern Mindanao breaking both Quaternary and Plio-Pleistocene rocks. Indeed, judging from the fault's general physiographic expression, Recent deposits are undoubtedly broken along most of its length throughout the Philippines, but this is difficult to prove in detail under tropical vegetative conditions and without a better knowledge of the age of the underlying rocks.

Further evidence of Quaternary displacements is given by closed depressions along the fault, which certainly cannot survive long in a region which not only has an annual rainfall exceeding 3 meters along much of the fault trace but can also claim some of the world's greatest short-period rainfalls associated with frequent typhoons. Probably the largest of these depressions is occupied by Lake Mainit in northeastern Mindanao. Lake Danao, $12 \mathrm{~km}$ northeast of Ormoc, Leyte, is clearly fault controlled, as are several other dry closed depressions nearby. Lake Danao's location at the acute junction of two closely divergent branches of the fault (Figure 2 , inset) appears to be a good example of the mechanism of graben formation by transcurrent movement proposed by Lensen [1958]. A sag pond bordered by fault scarps is illustrated by the small pond $3.7 \mathrm{~km}$ southeast of Bitulok, Luzon, near the crest of the fault saddle between Dingalan Bay and the Central Valley. In addition, a multitude of ponds and swampy areas along the fault in rice-paddy areas of Leyte, 


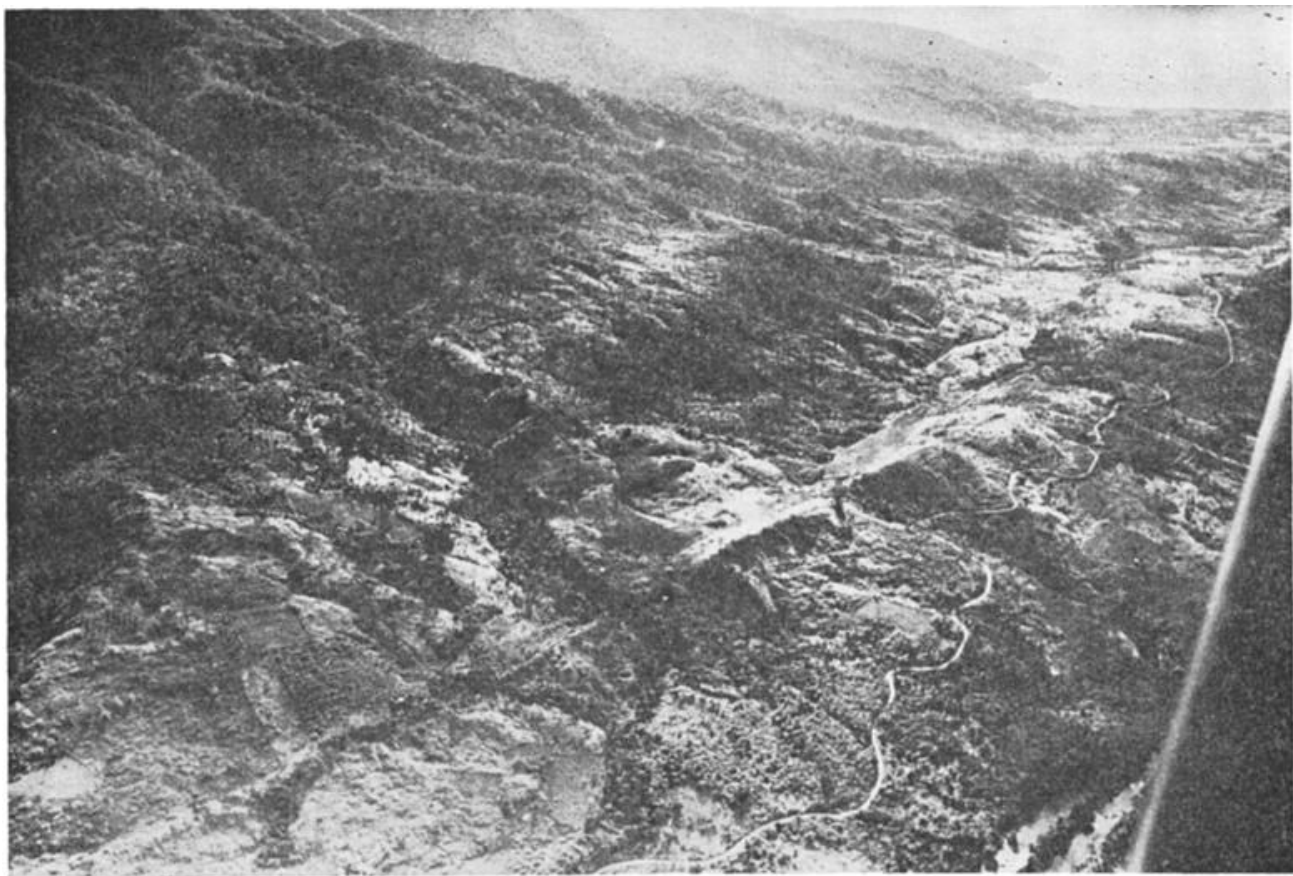

Fig. 6. Aerial view of Recent scarps of Philippine fault zone east from near Bitulok, Luzon, toward Dingalan Bay (background). Photograph taken from the help of W. R. Merrill.

Masbate, and Luzon probably are natural closed depressions, but these are hard to verify because of possible cultural modifications. On Leyte, the fault cuts across the flank of the volcanic cone of Mount Janagdan (Figure 2, inset), which, although not listed as active, must be of Quaternary age in view of the preserved crater lake at its summit. In central Leyte, the fault trace is not as clear as it is farther northwest. This is undoubtedly related to the abundance of Quaternary volcanic rocks in the area. Irving [1951] has discussed the submarine morphology along the Philippine fault, and his map shows elongate closed depressions along the extended trace of the fault between Alabat Island and Dingalan Bay, in Ragay Gulf, between Ticao and Masbate, between Leyte and northeastern Mindanao, and south of Mindanao.

Sense of displacement. The known juxtaposition of grossly different rock types along parts of the Philippine fault zone suggests that the displacement has been appreciable, and the existence of fault scarps in areas of low relief indicates that at least some of the component of displacement has been vertical. But several lines of evidence suggest that the over-all displacement during the fault's history has been primarily horizontal.

(1) The extreme linearity, or smoothness of curvature, of the fault trace over hundreds of kilometers is difficult to reconcile with anything but horizontal displacement. Similar linearity is characteristic of other great transcurrent faults (Figure 9) but is unknown on faults with predominantly vertical displacement. To the author, the linearity of the Philippine fault zone is in itself a diagnostic criterion of dominant horizontal displacement.

(2) Along most of the trace of the Philippine fault, neither side is consistently higher than the other. The principal exception is in northern Luzon, where the mountains are consistently high northeast of the fault. But in this area, individual Recent scarps at the base of the range exhibit varying and opposing vertical displacements, and the author suspects that even here the total horizontal component of movement has far exceeded the vertical. More typical is the situation in central Leyte and southern Mindanao, where the fault cuts obliquely across complete mountain ranges without apparent gross effect, in a manner similar to that of the 
San Andreas and Alpine faults in mountainous areas of southern California and New Zealand.

(3) Laboratory and theoretical studies of rock failure, in addition to a multitude of field observations, indicate that faults with predominantly vertical displacement tend to have dips significantly less than $90^{\circ}$. Yet everything that is known about the Philippine fault suggests that it is essentially vertical. The best evidence for this is the linear trace of the fault in areas of high relief. For example, southeast from the crossing of the Bao River in northern Leyte, the fault trace climbs more than 400 meters in less than $3 \mathrm{~km}$ with little, if any, change of trend.

(4) Individual parallel Recent scarps within the fault zone often have opposing senses of vertical displacement and in many places tend to 'scissor,' i.e., to reverse direction of throw at some point along the trace.

Granting the predominance of horizontal displacement, the sense of displacement-dextral or sinistral-is a much more elusive question. The author cannot accept the argument of King and McKee [1949, p. 1834] and others that 'the regional plan of the tectonic features' indicates sinistral displacement. The present distribution of land and water, as well as that of the various mountain ranges, appears to be far more a function of vertical than of horizontal movements. Nor, as was pointed out in the introduction, has the regional plan suggested the same sense of displacement to all investigators. And the conclusions based on the single set of slickensides on Masbate [Willis, 1937] obviously need further verification.

Stream offsets at numerous localities along the fault on Luzon, Masbate, and Leyte (Figure 7) powerfully and unequivocally demonstrate that the sense of Recent displacement is indeed sinistral. The fact that stream offsets survive at all in a region where erosional processes are as rapid as in the Philippines is strong evidence of the vigorous and continuing activity of the fault. Consistent and convincing stream offsets have been observed on all segments of the fault except on Mindanao, where most of the fault trace is obscured by swamps and flood-plain deposits of the Agusan River.

Development and preservation of stream offsets demands a unique environment: there must be sufficient relief so that streams are moderately entrenched, and the fault must cross drainages nearly at right-angles rather than follow a stream valley. This last condition is seldom realized, inasmuch as erosion of the pulverized rocks of the fault zone causes most streams to follow the fault rather than to cross it. Only where the fault locally climbs out of a canyon bottom, such as in crossing from one drainage system to another, does it cross numerous closely spaced tributaries; such is the situation in each of the three areas of Figure 7. Furthermore, unless the sense of displacement is such that the offsets are in the uphill direction, they might just as well be attributed to preferential erosion and stream piracy as to actual fault movement. Thus the three examples of Figure 7 are from areas in which the sinistral offset along the fault has displaced tributary streams in a direction opposite to that of the gradient of the main stream; under these circumstances, the consistent offsets shown could not reasonably have been developed by normal erosional processes and must have been caused by horizontal fault displacements.

The examples of Figure 7 represent three of the most diagrammatic localities of stream offsets that were found in an examination of aerial photographs, but they are by no means unique. Other areas of consistent sinistral offsets include (1) the zone of Recent faulting along the base of the range northeast of Umingan and Lupao, Luzon, (2) the segment of the fault between Visares and the Banalahang River, northern Leyte (Figure 2, inset), which includes the very sharp 350-meter offset of the Bao River marked by several spectacular steam-producing hot springs, and (3) the segment of the fault at the east base of the central range of Leyte, $14 \mathrm{~km}$ northwest of Abuyog. No areas were found in which one might make a reasonable argument for dextral offsets.

Insofar as is presently known, no geologic units are offset along the fault in such a way as to indicate the total amount of horizontal displacement. In addition to the lack of detailed geologic maps, much of the difficulty lies in the fact that large segments of the fault are under water, and even the parts that are exposed are largely within very young rocks. But judging from the horizontal displacements of hundreds of kilometers that have been proposed for other faults of similar length and regional importance, the possibility of very large total offset on the 


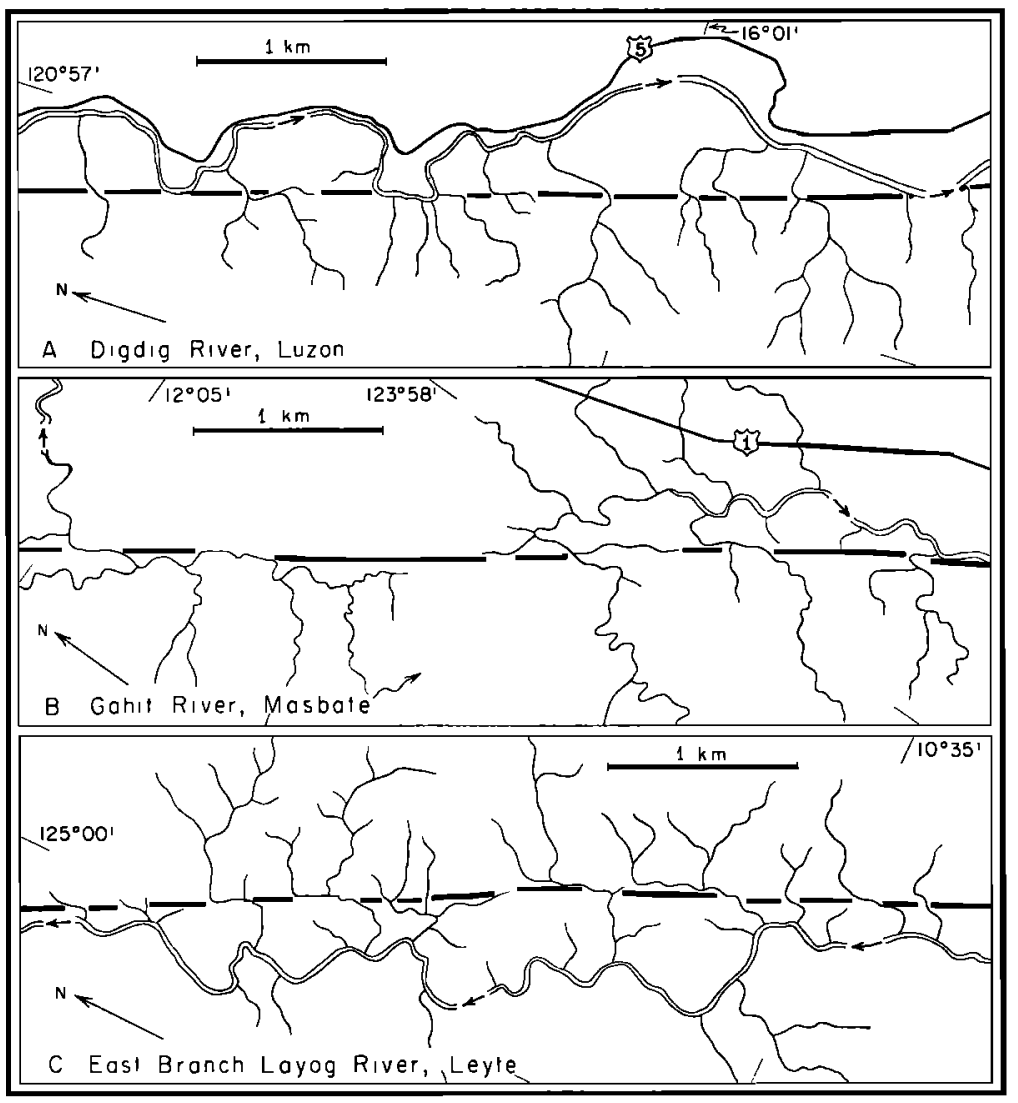

Fig. 7. Maps of sinistral stream offsets along Philippine fault.

Philippine fault should be kept in mind during further geologic mapping in this region.

Seismicity. If the Philippine fault zone is indeed active and perhaps the dominant tectonic feature of the archipelago, should one not expect to find earthquake epicenters aligned along its trace? A glance at the epicenter maps of the Philippines [Gutenberg and Richter, 1954; Miñoza et al., 1960, p. 62] is disappointing; epicenters depict the general trend of the archipelago but certainly cannot be construed to delineate the Philippine fault zone within it. In fact, most of the largest earthquakes of the region during this period (1907-1959) occurred elsewhere in the Philippines. One should note, on the other hand, that the diffuse spread of epicenters also typifies California and New Zealand, where active 'master faults' are well-documented features. Such major faults as the San Andreas are evidently characterized by great earthquakes at only infrequent intervals, al- though the tectonic strain release of one such great shock may be greater than the combined effect of smaller shocks over a wide region during the preceding hundred years. Thus the truly important tectonic-seismic events may not appear on an epicenter map that necessarily covers only a very limited time range.

As was stated in the introduction, no historic earthquakes along the Philippine fault are known to be unequivocally associated with actual surficial fault displacement. But several historic shocks were probably related to surface faulting, and if the historic record were more complete the Philippine fault zone might well appear more active than the better-known San Andreas and Alpine faults. For example, the great earthquake of August 16, 1869, was destructive throughout much of the central Philippines and was apparently centered near Masbate. Judging from reports of changes in ground level near Ticao and extensive 'cracks' in southern Masbate 
[Masó, 1895], this shock was probably associated with slippage along the fault's central segment, particularly inasmuch as the one area from which extensive cracks were reported is the only area where the active break crosses dry land in this region. Descriptions of the great Surigao, Mindanao, earthquake of July 1, 1879 [Centeno y Garcia, 1882], mention extensive fissuring and changes of ground level between Anaoan and Lake Mainit ('Lago Sapongan'), which is the exact line of the most recent appearing break on modern aerial photographs. One of the greatest earthquakes in Philippine history is that of June 21, 1893, in eastern Mindanao, which was clearly associated with widespread subsidences in the swamps of the upper Agusan River and with possible extensive faulting near the present town of Monkayo [Masó, 1910]. And the largest instrumentally recorded earthquake of the Philippines region ( $M=8.3$ ) occurred on April 14, 1924, along the projected trace of the Philippine fault south of Mindanao, at $61 / 2^{\circ} \mathrm{N}, 126^{1} / 2^{\circ} \mathrm{E}$. At Mati, where the most recent break of the fault goes out to sea, large-scale subsidence and possible faulting were reported at that time [Masó, 1924; Melendres and Comsti, 1951, p. 42].

Tectonic environment. The presence in the Philippines region of a great oceanic trench, abundant active volcanism, numerous serpentinitic intrusions, and earthquakes of shallow to deep focus indicate that this region is truly part of the circum-Pacific orogenic belt, although the diverse tectonic trends of the archipelago and the lack of alignment of volcanoes indicate that the region is hardly typical. The gentle curved traces of the Philippine fault and the Mindanao trench illustrate the arcuate structure, convex toward the Pacific, and the parallelism of these two features is remarkable. The axes of the trench and the fault are scarcely $150 \mathrm{~km}$ apart for long distances east of Mindanao, and one can hardly escape the conclusion that, if sinistral displacement is dominant on the Philippine fault, the Mindanao trench must share the same stress system and likewise exhibit a large component of sinistral transcurrent displacement. This conclusion is supported by the fault-plane solutions [Ritsema and Veldkamp, 1960], but fundamental questions are left unanswered as to the origin of this and other trenches.

The Philippine fault zone has no obvious di- rect relation to Quaternary volcanism; about as many volcanoes occur on one side of the fault as on the other, and no Quaternary volcanoes lie squarely within the fault zone, except possibly on Leyte. This appears to be in contrast to other great active transcurrent faults of the circum-Pacific region (Figure 9), where (1) the fault zone lies parallel to and between the trench and the line of active volcanoes (the Atacama fault of northern Chile [St. Amand and Allen, 1960] and possibly in northern New Zealand), (2) the fault itself is marked by a series of active volcanic cones (probably the situation in parts of Sumatra, southern Chile [St. Amand, 1961, p. 30], and possibly the Fossa Magna of Japan), or (3) there is little regional volcanism at all (along the San Andreas and southern Alpine faults).

The slight kink in the Philippine fault between Dingalan Bay and Alabat Island in Luzon is interesting because this is the only departure from the otherwise very smooth curve of the fault trace. If one visualizes the northeast coast of Luzon to be fault controlled, as is suggested by the deep offshore trough [Irving, 1951] and by the morphology of the coastline in the vicinity of the San Ildefonso Peninsula, then it is at the junction with this northeast-trending system that the bend in the Philippine fault takes place. And if the northeast-trending system is dextral, for which there is no evidence except its possible conjugate relation to the northwest-trending sinistral system, the bend in the Philippine fault is in the correct sense-in analogy to the bend in the San Andreas fault at its junction with the opposing Garlock fault. Indeed, even the angles between the fault systems are similar if one is viewed as a rotated mirror image of the other. Thus, perhaps the best evidence for dextral displacement on the northeast-trending system is the kink in the Philippine fault, although the absence of seismicity suggests that the northeast system-like the Garlock-may be currently inactive.

\section{Faulting in Taiwan}

Northern Luzon is far closer to Taiwan (Formosa) than it is to the southern islands of the Philippines, yet the tectonic relationship between Luzon and Taiwan is not at all clear. Wilson [1954, p. 184] considered the volcanic islands linking the two areas to be representative of a 
typical circum-Pacific arc between the Ryukyu arc to the north and the main Philippine arc to the south (Figure 1, inset); Taiwan itself could thus be visualized as a cap range or secondary arc at the acute junction of the Luzon and Ryukyu ares. Biq [1960] and Ho [1961] considered Taiwan to be an integral part of a primary double arc that is convex toward the Asian continent rather than toward the Pacific, with a corresponding reversal in the order of the associated tectonic features. Juan [1956, 1958] argued that Taiwan is a coastal range of the Asiatic mainland rather than an island are of the type represented by either the Ryukyus or the Philippines. The present study adds little to this particular problem but does indicate that major transcurrent faulting appears to typify Taiwan as well as other active circum-Pacific orogenic areas.

Central Taiwan is underlain by a surprisingly high and rugged longitudinal mountain range whose crest lies somewhat east of the island's center line. The eastern coastline of the island is consequently extremely precipitous in places, such as along the famous coastal cliffs between Suao and Hualien.2 But the central part of the east coast is bordered by a coastal range separated from the main backbone of the island by a conspicuous longitudinal valley between Hualien and Taitung that is aligned with the coastal cliffs to the north and south (Figure 8). Indeed, the consistent trend of the valley is so striking that it is commonly called simply the Longitudinal Valley, although many other terms have been used in the geologic literature. This valley, $150 \mathrm{~km}$ long and 5 to $10 \mathrm{~km}$ wide, is remarkable for its extraordinary linearity, its negligible relief as compared to the mountains on either side, and the very odd drainage pattern in which only one of the major rivers draining the central range manages to break through the eastern wall of the Longitudinal Valley which lies athwart the normal drainage paths. One could hardly hope to find a more diagrammatic example of a structurally controlled valley, and its fault origin has been recognized for many years [Omori, 1908, p. 164]. In addition to the gross physiography, the very different rock types of the Coastal Range and the Central Mountain

\footnotetext{
2 All place names used in this part of the text are indicated on Figure 8.
}

Range demand a fault contact along the axis of the Longitudinal Valley [Hsu, 1956], although the contact itself is everywhere concealed by alluvium. The much greater elevations west of the valley than to the east suggest a significant vertical component of displacement, and most authors have considered the faults underlying the Longitudinal Valley to be predominantly thrusts [Hsu, 1956, p. 59; Juan, 1958, p. 286; $B i q, 1960$, p. 209], although Biq argues for an additional component of sinistral displacement along the shallow thrust planes.

That the Longitudinal Valley is an active fault feature is indicated by historic great earthquakes, by consistently high seismicity, and by fault scarps that cut Quaternary alluvium of the valley floor. Scarps within the valley are not nearly as abundant as one might expect from the high seismicity, because active alluvial fans of rivers draining the Central Mountain Range literally inundate most of the adjacent tectonic trough. Annual rainfall in higher parts of the range exceeds 5 meters, and the steepness and height of the mountain front compare favorably with the great eastern escarpment of the Sierra Nevada in California. As a result, despite the otherwise subtropical environment, the immense, barren alluvial fans filling the Longitudinal Valley appear to be far more active than most typical desert fans. Along the Longitudinal Valley, therefore, it is only at drainage divides or otherwise protected points that one can hope to find Quaternary fault scarps preserved. Among the few such localities, pointed out to the author in the field by T. L. Hsu and C. S. Wang, are (1) the prominent scarp trending north from Hualien to the sea, associated with sag ponds along its base near the Hualien airport and (2) a distinct linear scarp at least $15 \mathrm{~km}$ in length that passes along the east shore of the fault-ponded Ta Po Chih near Chihshang. Scarps of at least two ages are present along the edge of the valley east of Fuyuan, relatively protected here because of their proximity to the drainage divide. All the above-mentioned scarps trend parallel to the Longitudinal Valley, but they are so scattered and so dissected that little information about the over-all sense of displacement can be gained. In no areas do incised streams appear to cross the breaks in such a way as to indicate or preclude lateral displacements. 


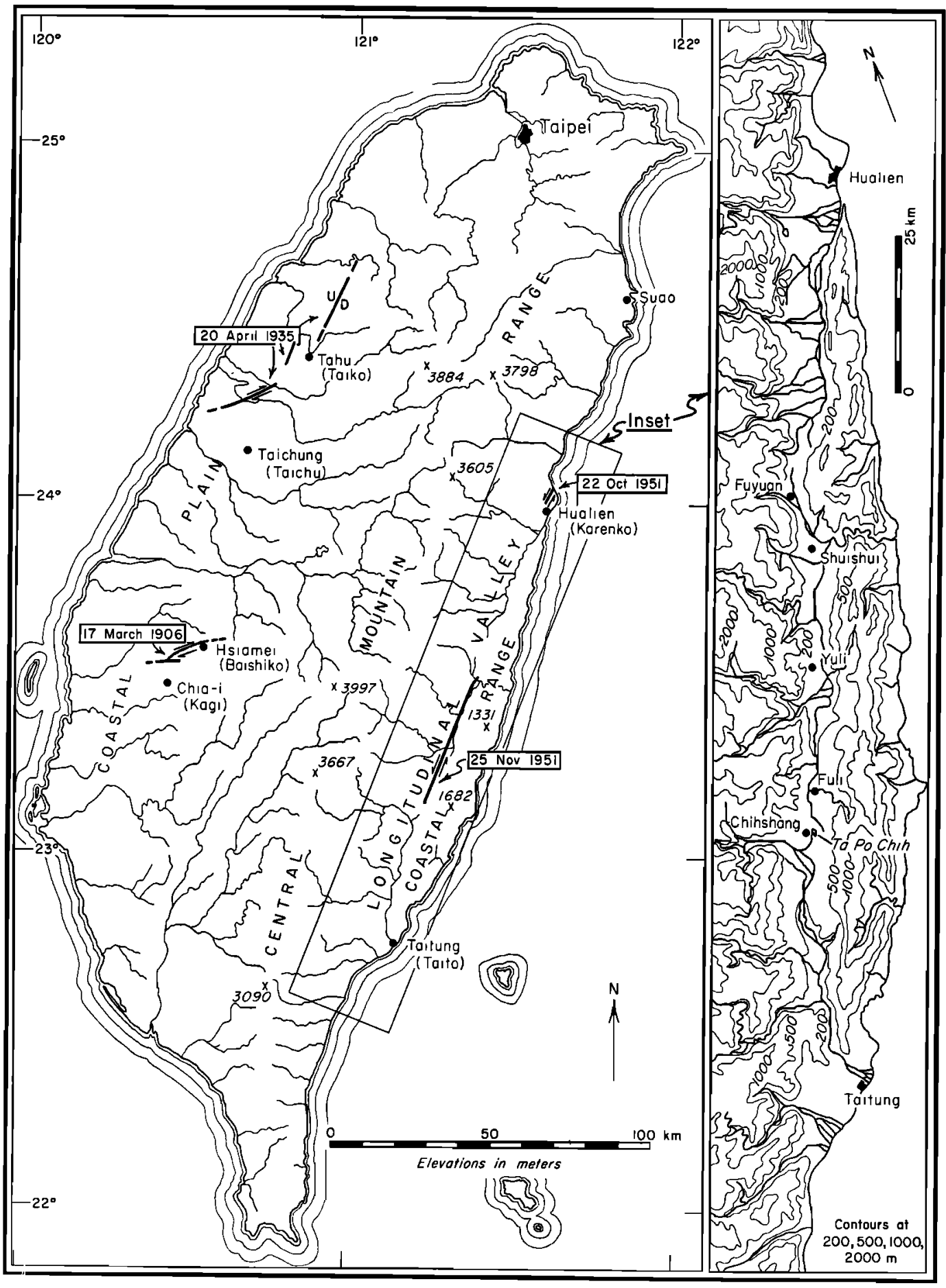

Fig. 8. Map of Taiwan (Formosa), showing faulting during historic earthquakes. Japanese names in parentheses. 
The most powerful line of evidence concerning the sense of displacement along the Longitudinal Valley comes from the major earthquakes of 1951, whose geological effects have been described by $H s u$ [1955, 1962]. The largest shock of this series $(M=7.3)$ occurred on November 25 and was associated with well-documented faulting centered near Yuli. Displacement took place along the fault trace for about $40 \mathrm{~km}$ from near Shuishui to near Fuli, within and parallel to the Longitudinal Valley. Strike slip was consistently sinistral, with a maximum displacement of $163 \mathrm{~cm}$ near Shuishui, and vertical displacement was intermittent, with the east block relatively raised as much as $130 \mathrm{~cm}$ in some localities [Hsu, 1955]. Most of the fault trace has been obliterated since 1951, but three offset school buildings in Yuli that were neatly transected by the fault remain standing in testimony to the sinistral displacement at that time. An earlier shock of the same series on October 22 had been centered farther north along the Longitudinal Valley and was associated with displacement for about $7 \mathrm{~km}$ along the base of the older scarp, north of Hualien. Sinistral displacement was 2 meters, and the east block was relatively raised 1 meter. Thus, from the available evidence, the current activity along the Longitudinal Valley appears to be dominantly transcurrent, as is indeed suggested and perhaps demanded by the extreme linearity of the valley. The author sees no reason to suppose that the controlling faults are thrusts, but instead visualizes them as essentially vertical fractures similar to those of other great transcurrent faults where the attitudes of the fault planes can be more satisfactorily determined. $H s u$ [1956] points out that the nearby longitudinal faults of the Coastal Range are nearly all east-dipping thrusts, but the association of thrust faults with major vertical transcurrent faults has been well documented in many areas of the world. The sense of displacement along the Longitudinal Valley at the present time is clearly sinistral, which obviously corresponds to the regional displacement along the Philippine fault zone farther south.

More widely known than the 1951 shocks are two earlier earthquakes in Taiwan that both demonstrated significant components of transcurrent displacement of dextral sense. Geologic effects of these shocks, in 1906 and 1935, have been summarized from the Japanese literature by Richter [1958], and the associated breaks are shown in Figure 8. As opposed to the 1951 earthquakes, both of the earlier shocks are on the west side of the island, and the parts of the breaks associated with dominant strike slip trend $\mathrm{N} \mathrm{60-70} \mathrm{E.} \mathrm{Thus} \mathrm{they} \mathrm{might} \mathrm{well} \mathrm{be} \mathrm{vis-}$ ualized as fractures conjugate to the 'master fault' represented by the Longitudinal Valley.

The linearity and continuity of the Longitudinal Valley fault zone emphasize the apparent truncation of tectonic elements of the Ryukyu arc by Taiwan. The Ryukyu trench and its southwestward extension (Figure 1, inset) would, if prolonged, butt into the east coast of Taiwan almost opposite the midpoint of the Longitudinal Valley. Likewise, the very smooth geanticlinal (nonvolcanic) axis of the Ryukyu arc [Hess, 1948] would intersect Taiwan at the north end of the valley near Hualien, yet there is little evidence of an impending major change in trend of the Longitudinal Valley fault system. It is difficult to escape the conclusion that this fault system and possible parallel offshore equivalents represent an actual truncation, and not merely sharp bending, of tectonic elements of the Ryukyu arc.

\section{Conclusions}

The results of this study tend to reinforce earlier observations made in northern Chile [St. Amand and Allen, 1960] which indicated that great transcurrent faults parallel to the oceanic margins are typical features of active circum-Pacific arcs and are not limited to unique or unusual areas. The best documented transcurrent faults have generally been considered to be the San Andreas fault of California and the Alpine fault of southern New Zealand, yet both of these areas are admittedly atypical of the circum-Pacific rim in that they lack intermediate and deep earthquakes, abundant volcanism, and oceanic trenches. But the Philippines and, particularly, northern Chile are so truly circumPacific in their structure that little doubt remains that major transcurrent faults must now be included among the typical tectonic features of the circum-Pacific 'ring of fire.' This point of view was emphasized by the great Alaskan earthquake of 1958 [Tocher, 1960], which was associated with almost pure strike slip in a region where most geologists probably would not have predicted this type of displacement. Fur- 


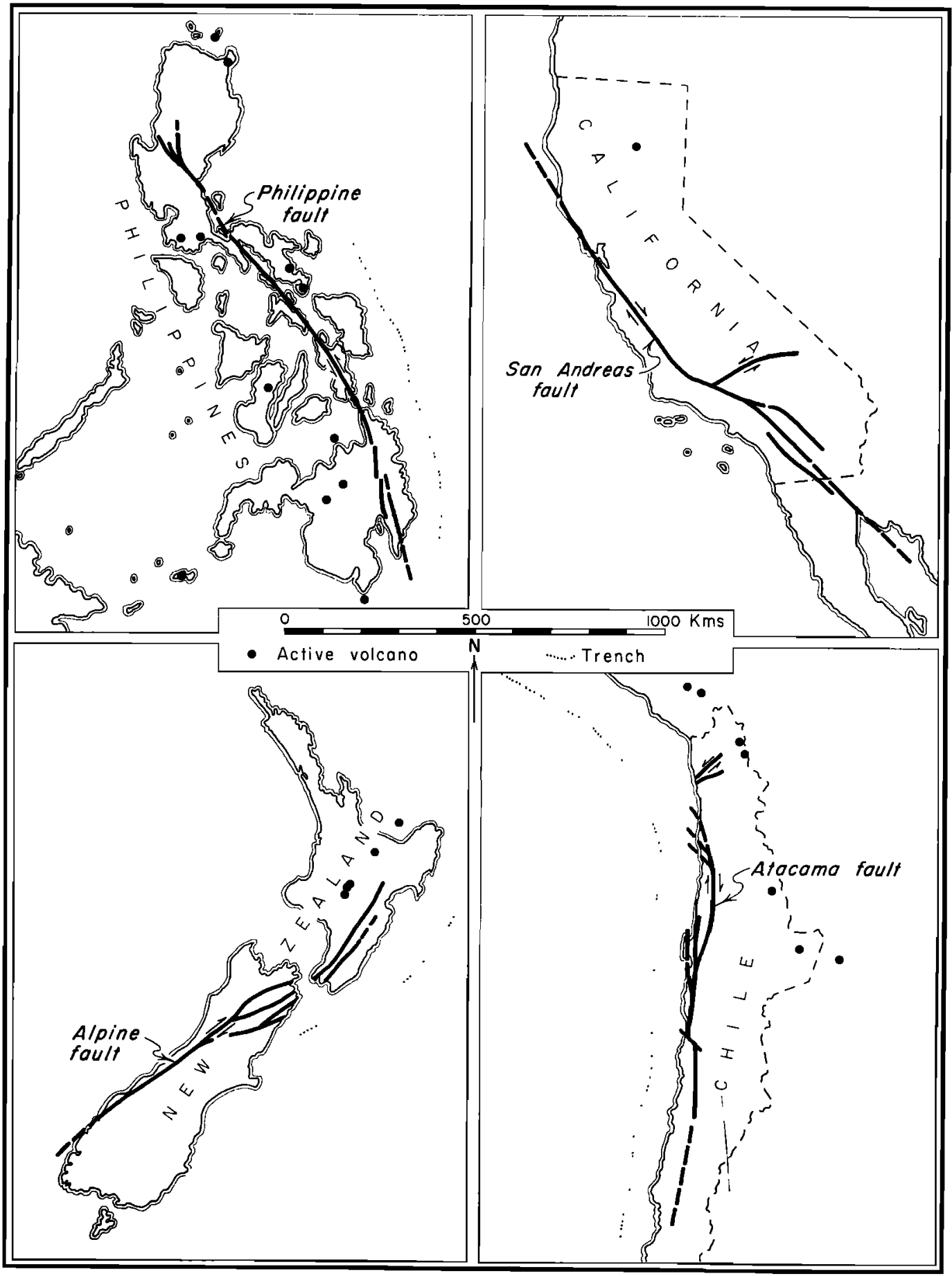

Fig. 9. Maps at same scale of Philippine, San Andreas, Atacama, and Alpine faults. 
thermore, the much-debated results of numerous fault-plane solutions which indicate that threequarters of the world's earthquakes are caused by dominantly transcurrent displacements [Hodgson, 1957; Scheidegger, 1959] begin to look more and more geologically reasonable.

The Philippine fault zone is physiographically and structurally fully as spectacular as the better-known San Andreas and Alpine faults, and certainly it deserves a place among these as one of the great regional tectonic features of the earth (Figure 9). Its current activity is demonstrated by abundant evidence of Recent and probably historic displacements, and consistent offset streams indicate that Quaternary displacements have been predominantly transcurrent and sinistral. In the opinion of the author, the linearity - or very smooth curvature - of the fault trace in itself demands a history of horizontal displacement, particularly if the total displacement has been at all large. The total length of the Philippine fault zone within the archipelago is more than $1200 \mathrm{~km}$, and its remarkable parallelism and proximity to the Mindanao trench suggest a close causal relationship between the two features. If the Philippine Islands were slightly more submerged, the trace of the fault would be largely concealed beneath the sea, and the author suspects that similar throughgoing fractures of transcurrent character probably underlie many of the less well exposed island-arc areas. Likewise, the $150-\mathrm{km}$ length of fault exposed in the Longitudinal Valley of Taiwan presumably represents only a short segment of its total length; everything that is known about this fault indicates that it, too, is a master fault of regional tectonic importance.

Regarding the question of possible counterclockwise rotation of the Pacific basin [Benioff, 1959; St. Amand, 1959], it seems clear that the sinistral displacement that prevails in the Philippines-Taiwan region is not in harmony with the dextral displacements that have been demonstrated in Alaska, California, Chile, and New Zealand. This point of view has previously been expressed by Biq [1958], and the principal contribution of the present study is not so much to refute the rotation hypothesis as to put forth concrete geologic evidence for the sense of displacement on major faults of the PhilippinesTaiwan region. Indeed, one might argue that the true edge of the rotating 'disk' is along the
Bonin-Mariana-Palau arc system, following the Andesite Line [Hess, 1948], rather than along the Ryukyu-Taiwan-Philippine system, and thus sinistral displacement in the latter area does not necessarily destroy the rotation hypothesis. On the other hand, there are a variety of reasons for arguing against the rotation hypothesis, the most cogent being the failure of the hypothesis to account for the convexity of the arcs or the acute cusps between adjacent arcs, as has been pointed out by Benioff [1962] in a recent reevaluation of the rigid rotation hypothesis. The pattern of individual currents underlying the circum-Pacific rim appears to be far more complicated than a single rotational cell. For example, demonstrated sinistral displacement in the Philippines and Taiwan area gives strong support to the proposal of Vening Meinesz [1954] that the Indonesian archipelago is being protruded southeastward toward Australia with accompanying sinistral shearing along the Philippine flank and dextral shearing along the southern flank. This theory is supported by observations of transcurrent faulting in Sumatra [Reid, 1913; Durham, 1940]. Similar complexities probably exist elsewhere (in Japan, for instance), where no clear-cut picture of systematic transcurrent displacements has as yet evolved.

Acknowledgments. This study was carried out with funds from the first Grove Karl Gilbert Award in Seismic Geology from the bequest of the late Harry 0 . Wood. The field work was possible only with the generous cooperation of the Geological Survey of Taiwan, Taiwan National University, Chinese Petroleum Corporation, University of the Philippines, Philippine Bureau of Mines, and numerous oil companies in the Philippines. I am especially indebted to field colleagues C. S. Wang, T. L. Hsu, C. Y. Meng, E. A. Gamus, J. Pilac, and E. V. Tamesis.

\section{REFERENCES}

Aki, K., Further study of the mechanism of circumPacific earthquakes from Rayleigh waves, $J$. Geophys. Research, 65, 4165-4172, 1960.

Alcaraz, A. P., The major structural lines of the Philippines, Philippine Geologist, 1(2), 13-17, 1947.

Alvir, A. D., A theory on the major tectonic structure of Luzon, Philippine Islands, Proc. Pan Pacific Sci. Congr., Brd Congr., 1, 451-454, 1926.

Alvir, A. D., The Philippine fault zone and its relation to Philippine structure, Philippine J. Sci, 74, 411-421, 1941.

Benioff, H., Circum-Pacific tectonics, Publs. Do- 
minion Observatory Otlawa, 20(2), 395-402, 1959.

Benioff, H., Movements on major transcurrent faults, chapter 4 in Continental Drift, edited by S. K. Runcorn, Academic Press, London, 1962.

Biq Chingchang, Is the Pacific basin rotating counter-clockwise? (In Chinese, English summary), Trans. Chinese Assoc. Advance. Sci., 2(1), 10-11 and 16-19, 1958.

Biq Chingchang, Circumpacific tectonics in Taiwan, Rept. Intern. Geol. Congr., 21st Congr., 18, 203$214,1960$.

Centeno y Garcia, J., Informe sobre los temblores de tierra ocurridos en el mes de Julio de $\mathbf{1 8 7 9}$, en el distrito de Surigao, isla de Mindanao, Bol. Comisión del Mapa Geológico de España, 9, 215-221, 1882.

Durham, J. W., Oeloe Aer fault zone, Sumatra, Bull. Am. Assoc. Petrol. Geologists, 24, 359-362, 1940.

Gutenberg, B., and C. F. Richter, Seismicity of the Earth, 2nd ed., Princeton University Press, Princeton, N. J., 1954.

Hess, H. H., Major structural features of the western north Pacific, an interpretation of H.O. 5485, Bathymetric Chart, Korea to New Guinea, Bull. Geol. Soc. Am., 59, 417-446, 1948.

Ho, C. S., Geologic relationships and comparison between Taiwan and the Philippines, Proc. Geol. Soc. China, no. 4, 3-31, 1961.

Hodgson, J. H., Nature of faulting in large earthquakes, Bull. Geol. Soc. Am., 68, 611-643, 1957.

Hsu, T. L., The earthquakes of Taiwan (in Chinese), Quart. J. Bank of Taiwan, $7(2), 148-164$, 1955.

Hsu, T. L., Geology of the Coastal Range, eastern Taiwan, Bull. Geol. Survey Taiwan, 8, 39-63, 1956.

Hsu, T. L., Recent faulting in the Longitudinal Valley of eastern Taiwan, Geol. Soc. China Mem. 1 , in press, 1962.

Irving, E. M., Submarine morphology of the Philippine archipelago and its geologic signifcance, Philippine J. Sci., 80(1), 55-88, 1951.

Irving, E. M., Geologic map sheets, Philippines, Proc. Pacific Sci. Congr., Pacific Sci. Assoc., 8th Congr., 1953.

Irving, E. M., and J. S. Teves, The Iloilo earthquake of January 25, 1948, Panay Island, Philippine Islands, Philippine Geologist, 2(2), 6-17, 1948.

Juan, V. C., Physiography and geology of Taiwan, Proc. Pacific Sci. Congr., Pacific Sci. Assoc., 8th Congr., 2, 281-312, 1956.

Juan, V. C., Continental rifting and igneous activities in the Neogene marginal geosynclines of Taiwan, Proc. Geol. Soc. China, no. 1, 27-35, 1958.

King, P. B., and E. M. McKee, Terrain diagrams of the Philippine Islands, Bull. Geol. Soc. Am., $60,1829-1836,1949$.

Leith, A., The geology of the Baguio gold district, Philippine (Commonwealth) Dept. Agr. and Commerce, Tech. Bull.9, 1938.
Lensen, G. J., A method of graben and horst formation, $J$. Geol., 66, 579-587, 1958.

Livingston, C. W., Mechanics of vein formation in the northern half of the Baguio district, $E n g$. Mining $J$, 140(9), 38-42, and 140(10), 49-51, 1939.

Masó, M. S., La seismología en Filipinas, Tipografía de Ramirez y Cia., Manila (Observatorio de Manila), 1895.

Masó, M. S., The seismic centers of Samar, Leyte, and eastern Mindanao, Philippine Weather Bur., Monthly Bull. Aug. 1910, 279-291, 1910.

Masó, M. S., The Mati earthquake, April 14, 1924, Philippine Weather Bur., Seismol. Bull. 1924, 1-2, 1924.

Melendres, M. M., Jr., and F. Comsti, Reconaissance geology of southeastern Davao, Philippine Geologist, 5(2), 38-46, 1951.

Miñoza, W. A., A. T. Ocampo, Jr., and S. Bellosillo, Jr., Significant Philippine earthquakes, 1949-1959, Philippine Weather Bur. Sci. Paper $101,1960$.

Noble, L. F., The San Andreas fault zone from Soledad Pass to Cajon Pass, California, chapter 4, pp. 37-48, in Geology of Southern California, edited by R. H. Jahns, California Div. Mines Bull. $170,1954$.

Omori, F., On the Bokusekikaku and Basshisho (Formosa) earthquake of January 11, 1908, Bull. Imp. Earthquake Investigation Comm. (Japan), 2, 156-165, 1908.

Ranneft, T.S. M., R. M.Hopkins, Jr., A. J. Froelich, and J. W. Gwinn, Reconnaissance geology and oil possibilities of Mindanao, Bull. Am. Assoc. Petrol. Geologists, 44, 529-568, 1960.

Reid, H. F., Sudden earth-movements in Sumatra in 1892, Bull. Seismol. Soc. Am., s, 72-79, 1913.

Repetti, W. C., Tectonic lines of the Philippine Islands, Philippine Weather Bur., Seismol. Bull. 1934, 57-71, 1935.

Richter, C. F., Elementary Seismology, W. H. Freeman and Co., San Francisco, Calif., 1958.

Ritsema, A. R., and J. Veldkamp, Fault plane mechanisms of southeast Asian earthquakes, Koninkl. Ned. Meteorol. Inst. Mededel. en Verh., no. 76, 1960.

Scheidegger, A. E., Statistical analysis of recent fault-plane solutions of earthquakes, Bull. Seismol. Soc. Am., 49, 337-347, 1959.

St. Amand, P., Circum-Pacific orogeny, Publs. Dominion Observatory Ottawa, $20(2), 403-411$, 1959.

St. Amand, P., Observaciones e interpretación de los terremotos Chilenos de 1960, Univ. Chile, Comunicaciones Escuela Geología, 1(2), 1961.

St. Amand, P., and C. R. Allen, Strike-slip faulting in northern Chile (abstract), Bull. Geol. Soc. $A m ., 71,1965,1960$.

Tocher, D., The Alaska earthquake of July 10, 1958: Movement on the Fairweather fault and field investigation of southern epicentral region, Bull. Seismol. Soc. Am., 50, 267-292, 1960.

Van Bemmelen, R. W., The Geology of Indonesia, 
Government Printing Office, The Hague, 1949. Vening Meinesz, F. A., Indonesian archipelago: a geophysical study, Bull. Geol. Soc Am., 65, 143164, 1954.

Von Drasche, R., Fragmente zu einer geologie der Insel Luzon (Philippinen), Gerold's Sohn, Vienna, 1878.

Willis, B., Geologic observations in the Philippine archipelago, Natl. Research Council Philippines, Bull. 18, 1937.

Willis, B., Philippine earthquakes and structure, Bull. Seismol. Soc. Am., 34, 69-81, 1944.
Wilson, J. T., The development and structure of the crust, chapter 4 in The Earth as a Planet, edited by G. P. Kuiper, University of Chicago Press, Chicago, Ill., 1954.

Wisser, E., Deformation in the Baguio gold district, Philippine Islands (abstract), Bull. Geol. Soc. Am., 50, 1943-1944, 1939.

Wisser, E., Preliminary notes on the relation of Philippine mining districts to the structural history of the archipelago, Philippine Geologist, $6(4), 77-84,1952$. 